\title{
Negotiating around Obstruction: Legislative Effectiveness in the US Senate
}

Travis Johnston, University of Massachusetts, Boston

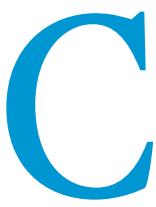

ongressional scholars have long studied how legislators approach their various responsibilities and how individual effectiveness relates to institutional productivity (Mayhew 1974; Hall 1998). Understanding what makes one legislator more effective than another is an important question and has received renewed attention in recent years (Volden and Wiseman 2014). Effectiveness, in short, is defined as the degree to which members successfully manage their legislative agenda, from introduction to the floor. The legislative process is fraught with institutional veto points and political pitfalls, a fact made all the more apparent in a polarized Congress (Theriault 2008). For legislation to successfully reach the president's desk, a bill requires considerable personal attention by a legislator capable of massaging it forward at each step of the process. This is particularly true in the US Senate, as I observed first-hand, where overcoming obstructionism is part and parcel to legislating (Wawro and Schickler 2007).

Drawing on my experience working on the Hill, this essay offers an inside perspective on what makes a senator effective: his or her ability to quietly navigate legislative obstructions. Informal bargaining throughout the legislative process is central to understanding lawmaking in the Senate. A legislator's effectiveness is best evaluated, as Hall (1998) argues, by observing the member's participation and effort inside and outside the committee room. The level of intensity brought to bear during these informal periods of negotiation is what separates the public-facing "show horses" from the efficient and capable "work horses." Effective legislators, and their staffs, labor behind the scenes in the hallways and private offices to ensure that their policy priorities are achieved. ${ }^{1}$ With the threat of a "hold" or filibuster looming over every legislative action, an effective senator, irrespective of seniority, must take her colleagues' demands seriously if she wishes to advance her agenda. Consequently, strategic members of both the majority and minority are capable of extracting seemingly small policy concessions that amount to significant victories in their own right.

In this essay, I describe how effective senators anticipate and navigate roadblocks imposed by their colleagues and outside groups alike. As a committee staffer, I was granted a unique vantage into the informal bargaining that occurs behind committee doors, a venue where neither the Congressional Record nor C-SPAN can go, and a place where a member's effectiveness is on display. Even amid periods of heightened partisan control (Sinclair 2006), committees remain the locus of legislative negotiations over big policy ideas and small phrasings alike. I conclude with a discussion of the essay's implications for studies on effectiveness in the Senate, and the need for greater attention to obstructionism and the relational aspects of legislating.

\section{MANAGING LEGISLATIVE NEGOTIATIONS, WORD BY WORD}

Prior to beginning negotiations to revise current law, committee staffers of both parties reach out to the legislative aides of senators "on committee" to establish the policy priorities of their co-partisans. Effective committee leaders and bill sponsors recognize that a top-down approach that ignores the wishes of their fellow committee members is unsuccessful in the long-term. By soliciting priorities early, the senators and their staffs can ensure that the version of the bill that reaches markup will reflect the wishes of their fellow committee members, thereby avoiding last minute surprise amendments. If the ultimate goal is to report the bill out of committee with a chance of passing on the floor, ${ }^{2}$ then extensive public debate serves little good. Markups that appear scripted and move at an efficient pace should not be taken as evidence of blissful policy agreement, but rather a sign of effective management by committee leadership and the bill's sponsors.

Gathering the views of members is particularly important given the multi-faceted nature of most policy issues. An education bill, for instance, cuts across numerous jurisdictions, from workforce development and job training to health care and criminal justice. For legislators, the bill represents an opportunity to drive home a policy win on their pet issue. Indeed, it is not uncommon for a meeting, ostensibly on priorities for an education bill, to focus entirely on whether the legislation's allowable use of funds includes a call-out on strategies to reduce recidivism or promote public-private partnerships. Anticipating, collecting, and managing these priorities is a crucial step in the legislative process, and one that effective senators must master in order to avoid future roadblocks.

After the solicitation of member priorities, informal bill negotiations can begin in earnest. Three sets of actors are central at this stage, beginning with the committee's chair 
and ranking member. The chair and ranking member command significant latitude over the committee's agenda, and the manner in which the leaders comport themselves helps establish the parties' working relationship on the committee. 3 Moreover, the chair and ranking member play key roles in organizing and directing the informal committee negotiations. Second, in the event that the bill's sponsor is on committee, as is often the case, then the senator functions as a key battle over what goes into a bill turns on who will be charged with enforcing the law, and how discretion on their part may subvert congressional intent (Huber and Shipan 2002). Proponents of federal action worry that local agencies will look for ways to shirk or water down the legislation, while states' rights advocates perceive new concepts or additional words as a potential opening for federal regulators. These concerns have been particularly salient in the wake of the Obama

\section{Gathering the views of members is particularly important given the multi-faceted nature of most policy issues. An education bill, for instance, cuts across numerous jurisdictions, from workforce development and job training to health care and criminal justice.}

advocate during the committee stage. Third, knowing that the bill requires bi-partisan support to clear the chamber, many pieces of legislation begin with a co-sponsor from the opposite side of the aisle. Along with the senator who introduced the legislation, the co-sponsor works with committee leaders to ensure that the final product will be reported favorably. In the absence of deft handling by committee leaders and committed sponsors, most legislation would meet an unceremonious end. Negotiations over seemingly innocuous language can devolve into debates over much larger philosophical differences, but a team of policy advocates can help navigate these partisan minefields. When such fights do erupt, staffers try to "bracket" those discussions for another day, thus allowing each side to weigh the entirety of the bill against the present sticking point. So long as both sides prefer the current working version to the status quo, then progress can still be made.

Legislative effectiveness, however, does not stop with committee leaders and bill sponsors. Important policy contributions, often in the form of a single word change, can originate with senators on and off committee. Indeed, relatively small changes to a single word or clause can have large substantive effects. Consider a scenario in which policy makers are negotiating over the use of funds for a specific grant program, and must decide whether the lead-in to the section uses a "shall" or a "may." The potential ramifications of this choice are profound. By opting for the latter, state agencies and grant recipients would have greater discretion over how the funds are spent, thus limiting or expanding the scope of the program. Moreover, this generates concerns as to whether different recipients under the same grant program are substantively comparable and can be evaluated in the same manner. These are important questions, but are they worth sinking a bill over? While this might appear like a minor point to the bill's sponsor, demanding that the draft use "may" could produce a significant victory to her colleague. The wording change provides an opportunity for the senator to return home to claim credit for having averted a policy disaster for her state.

\section{NAVIGATING AGENCIES AND MOBILIZED INTERESTS}

When negotiating the content of legislation, effective senators are acutely aware of how a specific clause may be interpreted by federal and state agencies. Indeed, much of the administration's proposed regulations on "gainful employment," often playing out in contentious debates over whether and how to define a term. 4

Questions on how to conduct oversight, though technically a concern of implementation and not lawmaking, are a vital part of the legislative process. For senators looking to enact their agenda, legislative discussions around reporting requirements and accountability measures provide an opportunity to "stack the deck" in favor of a particular outcome (McCubbins, Noll, and Weingast 1987). Despite a growing bi-partisan consensus on the need for better information on government programs, considerable disagreement persists over how to collect those data. For example, what is the appropriate level of granularity for data on a workforce program designed to provide job training to displaced workers? Proponents of collecting more fine-grained data will contend that complete information is necessary for assessing a program's efficacy among participants of various subgroups. Opponents, by contrast, will argue that such demands are excessively onerous and burdensome for states and localities. This debate, however, carries much larger implications. Without disaggregated data, it is impossible to definitively identify whether the policy is discriminatory or overlooking specific populations. In short, by fighting for more expansive reporting requirements, advocates are establishing the foundation for future discussions on program improvement and, potentially, opening the door for groups to bring civil rights complaints.

Policy disagreements aside, legislators have strong political incentives to disagree. Principled ideological stands, as Lee (2009) contends, are by no means the entire explanation for legislative stalemate. Denying the other team a political victory, especially heading into an election, is an important consideration to party leaders. This state of continuous conflict, however, is not entirely the making of political elites (Layman et al. 2010). Indeed, many issues that would otherwise go unnoticed in private negotiations have the potential to instigate public backlash among the party's core supporters. No senator wants to return to her state and face down a hostile crowd of activists or disgruntled policy demander, two groups who remain vigilant during the legislative process (Bawn et al. 2012). Consequently, informal negotiations 
around seemingly innocuous policy language can turn into entrenched partisan turf wars.

For instance, it is not uncommon for productive discussions on legislative text to be suddenly derailed over the inclusion of a specific term in a long list of call-outs. The offending phrase, ironically, may actually be current law, and of no import to the bill's sponsors and interest groups committed to the law's committee's ranking members and entrepreneurial work horses. More importantly, such analysis offers evidence into how bargaining is essential to crafting a final package suitable to overcoming obstruction.

Second, future work should continue to unpack the relational aspects by which an individual senator is capable of promoting her agenda. How does a senator's full retinue of

\section{Despite a growing bi-partisan consensus on the need for better information on government programs, considerable disagreement persists over how to collect those data. For example, what is the appropriate level of granularity for data on a workforce program designed to provide job training to displaced workers?}

reauthorization. However, even boilerplate text can contain loaded terms to mobilized activists among the politician's base. During informal negotiations, members and their staffs will readily acknowledge that such discussions are politically motivated, but these pressures are no less real if the senator wishes to remain in office. Members are loath to be on the record supporting language that can be distorted on social media or used in an attack ad. These concerns are partially responsible for the rise of overly complicated "cut-and-bite" amendments. Rather than submitting a clean, readable revision of current law, a bill's sponsors will amend sentence by sentence or word by word, thereby avoiding controversial clauses. Members are still on the record voting for the final bill, controversial language and all, but avoid having to introduce legislation that contains the problematic phrase or loaded term. Effective senators, and their staffs, cautiously navigate these pitfalls, otherwise the bill may die in committee despite any real ideological disagreement over the content.

\section{CONCLUSION}

Understanding what defines an effective legislator is both conceptually and methodologically challenging. Early work on legislative behavior engaged this question through in-depth examinations of how members of Congress weigh their decisions and allocate their finite resources in turn (Mayhew 1974; Fenno 1978; Kingdon 1989). In recent work by Volden and Wiseman (2014), the authors carefully track bill introduction data to assign legislative effectiveness scores to members. Volden and Wiseman's work represents an important contribution, and raises new questions on how we are to conceptualize and study the qualities that make one legislator more effective than another.

In engaging this debate, we must first acknowledge that significant legislative contributions frequently occur behind closed doors. Consequently, quantitative measures alone may be insufficient at capturing a senator's impact, particularly if the bill's secondary sponsors or committee leaders do not receive credit for their participation. Beyond collecting additional data on bills and amendments, 5 how should researchers studying effectiveness measure the concept? First, by qualitatively studying committee negotiations, we can gain deeper insight into the policy changes that are brokered between a positions strengthen her bargaining position with colleagues? For instance, if a member sits on both the authorization committee and appropriations subcommittee of a single policy area (e.g. Committee on Energy and Natural Resources, Subcommittee on Energy and Water Development) then the senator wields potentially greater authority when negotiating deals. Even in today's polarized Congress, relationships and cross-party collegiality are essential to Senate lawmaking, if for no other reason than the threat of obstruction.

Finally, how senators avoid and manage the opposition's obstructionist tactics is a key factor to understanding lawmaking effectiveness. A sufficiently motivated individual can cause immense trouble if they are unwilling to compromise on one phrasing over another, but to treat the filibuster solely as a hurdle to overcome is a mistake. Preventing a bill's passage offers "gains" in its own right. For senators who wish to restrict the size of government, legislative gridlock can deliver political and electoral benefits. If ideological obstinacy is a key piece of a member's individual agenda, and is applauded by her core supporters, then obstruction is evidence of her effectiveness.7 Beyond these broader attacks on government, obstruction can also produce concrete policy wins by helping to retrench existing policies that are difficult to dismantle (Hacker 2004). Scholarship on legislative effectiveness, at least in the Senate, must reconcile with both of these facets of obstruction if we are to fully appreciate the various paths a senator can take in the pursuit of her individual agenda.

\section{NOTES}

1. It is important to note that effectiveness is not defined in collective terms. In other words, being an effective legislator does not necessarily entail working to ensure that the chamber resolves the pressing issues before Congress (Mayhew 1974). Effectiveness, following Volden and Wiseman (2014), is merely the degree to which a member is capable of promoting his or her individual agenda.

2. This is a big assumption. Committees regularly schedule hearings that have no apparent goal beyond offering an opportunity for member position-taking. While such hearings may not contribute to a member's effectiveness in passing legislation, these symbolic gestures afford a chance to be heard publicly on issues that are important to the member and his supporters.

3. To be sure, countless other factors including the committee's jurisdiction contribute to its culture. Committees that handle controversial issues (e.g., Judiciary) or contentious redistributive policies are prone to more partisan bickering. That said, the Senate HELP Committee, which deals with a host of thorny issues, has been remarkably collegial under the 
leadership of Chairman Lamar Alexander (R-TN) and ranking member Patty Murray (D-WA).

4. One of the essential sections to every law is a list of definitions, but the section is more than an enumeration of acronyms and jargon. The "Definitions" section constitutes a list of the core issues at stake in the law, and increasingly represents an important point of legislative contestation, especially if doing so forecloses future encroachments by executive branch officials.

5. Better data is particularly relevant when it comes to amending behavior For instance, how should we think about situations in which floor leaders (usually the committee's ranking members) will put together a "manager's package"? These carefully negotiated bundles typically combine multiple amendments and have the potential to radically change a bill.

6. Beyond classifying a legislator's formal positions, scholars should consider the senator's entire package holistically (e.g., related committee assignments, standing with respect to caucus leadership, relationship with outside groups or ideological factions), and how these positions open-up additional opportunities.

7. This notion that individuals are sent to Congress to disrupt the process has become increasingly common since 2010. While more prevalent in the House, a number of conservative senators actively espouse such viewpoints and evaluate their effectiveness in these terms, at least partially.

\section{REFERENCES}

Bawn, Kathleen, Martin Cohen, David Karol, Seth Masket, Hans Noel, and John Zaller. 2012. "A Theory of Political Parties: Groups, Policy Demands and Nominations in American Politics." Perspectives on Politics 10 (3): $571-97$.

Fenno, Richard F. 1978. Home Style: House Members in Their Districts. Boston: Little, Brown
Hacker, Jacob S. 2004. "Privatizing Risk without Privatizing the Welfare State: The Hidden Politics of Social Policy Retrenchment in the United States." American Political Science Review 98 (2): 243-6o.

Hall, Richard L. 1998. Participation in Congress. New Haven: Yale University Press.

Huber, John D., and Charles R. Shipan. Deliberate Discretion? The Institutional Foundations of Bureaucratic Autonomy. Cambridge: Cambridge University Press, 2002.

Kingdon, John W. 1989. Congressmen's Voting Decisions. Ann Arbor: University of Michigan Press.

Layman, Geoffrey C., Thomas M. Carsey, John C. Green, Richard Herrera, and Rosalyn Cooperman. 2010. "Activists and Conflict Extension in American Party Politics." American Political Science Review 104 (2): 324-46.

Lee, Frances E. 2009. Beyond Ideology: Politics, Principles, and Partisanship in the US Senate. University of Chicago Press.

Mayhew, David R. 1974. Congress: The Electoral Connection. New Haven: Yale University Press.

McCubbins, Mathew, Roger Noll, and Barry Weingast. 1987. "Administrative Procedures as Instruments of Political Control." Journal of Law, Economics, and Organization 3 (2): 243-77.

Sinclair, Barbara. 2006. Party Wars: Polarization and the Politics of National Policy Making. Norman: University of Oklahoma Press.

Theriault, Sean M. 2008. Party Polarization in Congress. Cambridge: Cambridge University Press.

Volden, Craig, and Alan E. Wiseman. 2014. Legislative Effectiveness in the United States Congress: The Lawmakers. Cambridge: Cambridge University Press.

Wawro, Gregory J., and Eric Schickler. 2007. Filibuster: Obstruction and Lawmaking in the US Senate. Princeton: Princeton University Press. 